\title{
New Directions for Refugee Determination and Protection in Canada
}

\author{
Sharryn Aiken
}

\begin{abstract}
This article is a review and analysis of the Canadian government's recent "white paper" on immigration and refugee policy and legislation. This review focuses on the proposals related to inland refugee determination and protection. While noting a number of positive initiatives in the document, the author expresses concern about the future of Canada's role in refugee protection in the next millennium.
\end{abstract}

\section{Précis}

Cet article passe en revue et analyse le récent «livre blanc» du gouvernement canadien sur les législations et politiques en matière de réfugiés et d'immigration. Cetteanalyse concentre sonattention sur les propositions formulées en matière de détermination et de protection des réfugiés intra-nationaux. Signalant un certain nombre d'initiatives positives dans ce document, l'auteur exprime malgré tout son inquiétude sur l'avenir du rôle $d u$ Canada en matière de protection des réfugiés dans le prochain millénaire.

In February 1998 the Canadian government funded the chartering of an airplane which returned a boat load of 192 Tamil asylum seekers to Sri Lanka. Soon after their boat was intercepted by the Senegalesenavy off the coast of Senegal, the Tamils were "voluntarily" on their way home where they were all arrested and held in detention for several weeks. At least one of these individuals was subsequently rearrested and tortured. In the only public acknowledgment of this interdiction action almosta

Sharryn Aiken is Past President of the Canadian Council for Refugees. She is director of the Centre for Refugee Studies' Summer Course on Refugee Issues, and director of Refugee Law Judges Training.

The assistance of Janet Dench, Executive Director of the CCR is gratefully acknowledged. full year later, a Canadian government spokesperson boasted of the success in saving the country from "illegal economic immigrants." 1 The government seems tohave overlooked itsobligations pursuant to the United Nations Convention against Torture not to return anyone (including alleged members of militant groups such as the Liberation Tigers of Tamil Eelam) to a country where there are substantial grounds for believing that sheorhewould be at risk of torture. ${ }^{2}$ Implicit in the obligation to respect the principle of non-refoulement is the necessity to implement adequate procedures to identify people who may be at risk of human rights violations if returned to their home country. Sri Lanka is a country in which the arrest, abuse and torture of Tamils by state security forces continues to be widespread. ${ }^{3}$

Meanwhile, here in Canada, the deportation of persons at risk, despite intervention by Amnesty International, and in two egregious cases, in direct contravention of formal requests made by international human rights bodies, have become increasingly common. 4 Current concerns include the imposition of a $\$ 975$ "right of landing fee" on every adult refugee applying for permanent residence, the thousands of Convention refugees in interminable limbo because of "unsatisfactory" identity documents ${ }^{5}$ or for security reasons, ${ }^{6}$ as well as the long delays and procedural obstacles associated with family reunification.

In 1979, Canada played a leading role in resettling tens of thousands of Vietnamese refugees in the aftermath of a decades-long war. While the government condemned the interception and piracy of Vietnamese boats on the high seas, it was forging innovative partnerships with private groups across the country to receive and support the refugees. As a result of these efforts the United Nations awarded the people of Canada the prestigious Nansen Medal, "in recognition of their major and substantial contribution to the cause of refugees." In 1989 the government established the Immigration and Refugee Board, principally in response to the Singh case, a landmark decision by the Supreme Court. ${ }^{7}$ The Supreme Court had ruled that fundamental justice required that credibility be determined on the basis of an oral hearing. Refugees and refugee advocates hailed the decision and the newly constituted Convention Refugee Determination Division as a major step forward. Canada's record of respect for international human rights standards and the Refugee Convention in particular has been uneven, however. The fundamental flaws in Canada's refugee determination system lie not so much with the determination procedures, but with the barriers to access, the politicization of the appointments process and the competence of Board members as well as the lack of appeal on the merits of a negative decision. As for inland refugee protection issues, the vast majority of current concerns emanate from government policy initiatives that trace their genesis to the early 1980s with the onset of globalization and the push for international migration control. As borders havebecome increasingly porous to facilitate the movement of goods and capital, Canada has been steadily embracing concomitant restrictions on freedom of movement for people, even as the official rhetoric suggests otherwise: ${ }^{8}$

After completing a series of public consultations beginning early in its first term and more recently, in conjunction with the legislative review process initiated in late 1996, the federal government finally unveiled its proposals for reform: Building on a Strong Foundation for the 21st Century: New Directions on Immigration and Refugee Policy and Legislation (New Directions). Not quite the dramatic institutional and legislative overhaul recommended by the Minister's advi- 
sory group in Not Just Numbers, ${ }^{9}$ nevertheless the document merits careful scrutiny in a number of critical areas. What follows below is a brief review and reaction to the government's proposed directions for inland refugee determination and protection. ${ }^{10}$

\section{Compliance with Human Rights Standards}

New Directions proposes to adjust the objectives of the Immigration Act to "reflect evolving values." The new Act would differentiate between the refugee and immigration programs and clearly set out the overall objectives and components of each program. New Directions refers to protection decisions being made with reference to Canada's obligations under the Convention Relating to the Status of Refugees and "other instruments to which Canada is signatory and that relate to the life and security of the person such as the Convention against Torture." The document fails to identify compliance with the Canadian Charter of Rights and Freedoms, the International Bill of Human Rights and other relevant human rights instruments which Canada has ratified as an overall objective, however. Rather than respect for human rights, enforcement and the need to buttress Canadian borders appear to be the paramount objectives of New Directions.

It is time to end the incongruity between Canada's work in the international arena promoting compliance with international and regional human rights treaties while failing to take the necessary measures at home to implement the treaties the government has ratified and pledged to uphold. As recommended by the Canadian Bar Association, any person who seeks admission to Canada on either a permanentor temporary basis or who is subject to removal proceedings should be accorded treatment that is consistent with the Charter as well as Canada's international legal obligations. ${ }^{11}$ The new Act should explicitly adopt and incorporate all relevant international human rights standards, including the Beijing commitments with regard to women, a glaring omission in existing legislation.

\section{Consolidated Decision Making}

New Directions proposes to retain the Convention Refugee Determination Division of the IRB and consolidate responsibility for decision making with regard to refugee status and other protection claims within the Board. Implicit in this proposal is the positive recognition that all decisions with regard to risk and protection should be made by an independent, quasi-judicial tribunal. Within the context of a single hearing, claims should only be reviewed for protection on the basis of risk other than that covered by the refugee definition after the refugee determination and there should be a definitive decision on the merits of the refugee claim in all cases. This is critical in order to ensure that access to the greater protection afforded by Convention refugee status is maintained. It is also important in terms of ensuring consistent jurisprudence in this area.

Included in the section on consolidated decision making is a proposal for pre-removal risk assessment, "in appropriate circumstances." At theoutset, it must be emphasized that any consolidation of decision making within the IRB should noteliminate the right of preremoval risk assessment to the full range of individuals who may not have made a refugee claim in the first place as well as persons who may be subject to removal on grounds of criminality or threats to national security. Exclusion of any class of persons from such a risk assessment is inconsistent with Canada's international legal obligations, including the Convention against Torture. Consideration must be given to establishing transparent procedures by which the pre-removal risk assessments are conducted and which comply with international human rights standards as well as the basic principles of fairness and due process.

\section{Front-end Screening/Admissibility}

The government proposes to engage administrative officials in more comprehensive front-end screening of refugee claimants. Yet existing eligibility criteria are already inconsistent with the
Refugee Convention and the Convention against Torture. The IRB has themandate to exclude undeserving refugees from protection, and that is where decisions related to exclusion should be made. Furthermore, front-end screening adds a layer to the determination process. Any additional layers are resource intensive and necessarily producedelays. To the extent that few claimants are excluded in the existing eligibility process, a more efficient and just alternative would be the immediate referral of all claims to the IRB for determination.

The existing definitions in the Immigration Act relating to criminal and security inadmissibility are far too broad and the procedures currently applied fail to respect international standards. ${ }^{12}$ New Directions fails to address admissibility issues in the context of Canada's international legal obligations relating to refugees and others at risk of serious human rights violations. Rather than seeking ways to remedy the significant deficiencies in existing procedures, ${ }^{13}$ the government is proposing to add at least three new inadmissible classes to the Immigration Act. ${ }^{14}$ The Refugee Convention itself recognizes a government's right to expel where there is evidence that the refugee is a national security threat or has been convicted of a "particularly serious crime" and constitutes a genuine public danger. ${ }^{15}$ However, even in those cases, an individual can never be returned to a country where he or she faces a serious risk of torture, disappearance or extrajudicial execution. As recommended by Amnesty International, dëcisions on these matters should be made by the IRB and not, as is currently the case, by immigration officers and adjudicators. ${ }^{16}$

\section{Prescribed Time Frames}

New Directions proposes to impose a thirty day time frame for making a refugeeclaim, subject toexceptions in "compelling circumstances." The imposition of a rigid time frame, whether it is three days (as recommended in Not Just Numbers), thirty or even three hundred days violates international standards. The Executive Committee of the Office of the United Nations High Commissioner for 
Refugees has concluded that, "While asylum seekers may be required to submit their asylum requests within a certain time limit, failure to do so, or the non-fulfilment of other formal requirements, should not lead to an asylum request being excluded from consideration. "17 Canada is a member of the Executive Committee and supported this conclusion at the time it was passed. ${ }^{18}$

A prescribed time frame will have an adverse impact on certain groups of refugee claimants, particularly women fearing gender-based persecution and anyone with claims based on sexual orientation. These groups are least likely to be informed of their right to make a refugee claim and often face formidable barriers in terms of accessing the necessary support and assistance to initiate a claim. While current statistics may confirm that the vast majority of refugee claimants actually make their claims within a thirty-day period, a rule which provides for exceptions only in compelling circumstances will certainly result in serious injustice. A prescribed time frame would prohibit or certainly impede sur place refugee claims yet the Refugee Convention recognizes that protection may be needed based on events that happen long after a person has left home. As an alternative to a prescribed time frame, the existing practice of requiring the refugee claimant to explain the reasons for any delay in making their claim in the hearing itself should be continued. The claimant has the burden of providing a reasonable explanation for the delay and if unable to do so, the claim may be rejected.

\section{Second/Multiple Claims}

New Directions includes a proposal for the blanket elimination of the right of access to a refugee hearing for all failed refugee claimants who return to Canada after 90 days. Such an arbitrary rule fails to distinguish between those persons who have returned to Canada after 91 days versus those who have returned after many years and a clear change of conditions in their country of origin. It fails to distinguish between those few individuals who may indeed be abus- ing a revolving door of refugee protection from those persons who are forced to initiate a second claim after 90 days due to the incompetence or absence of counsel at their first hearing, the lack of an appeal process to adequately correct mistakes made at the first instance, as well as the restrictive provisions under which a refugee claim can be re-opened for consideration of new evidence. Given the diversity and complexity of factors which may result in persons seeking to initiate second refugeeclaims in Canada, the existing practice of providing access to a full refugee hearing and placing the burden on the claimant to establish the basis of their second claim should be continued. In the medium term, the Board should collectstatistics on the number of second claims being processed and the acceptance rates in relation to these claims. It is likely that this information will obviate the need for an absolute bar to second or even multiple claims.

\section{Manifestly Unfounded Claims and Safe Countries}

New Directions proposes to give priority to the processing of manifestly unfounded claims. Yet "manifestly unfounded" is a deeply flawed concept. Refugee status determination requires extremely sensitive and individuated assessments. The key to meeting the requirements of the refugee definition very often rests with evidence of a government's inability to protect a particular individual. While the proposal for priority processing is much less draconian than what has been adopted in many European states and in the United States, it is still problematic. The manifestly unfounded label would be highly prejudicial to a fair assessment of an individual's refugee claim. In the absence of concrete details with regard to how the "priority" might actually be applied, it is important to emphasize that all refugee claimants should have equal access to a refugee hearing with sufficient time to retain counsel and prepare for their refugee hearings.

New Directions also proposes to identify "safe countries" of origin which would constitute the basis for a mani- festly unfounded designation. Yet, human rights violations occur throughout the world. Even highly advanced, democratic countries will produce bona fide refugees from time to time. In fact, there maybesafe peoplebut there areno safe countries. ${ }^{19}$

\section{Ministerial Intervention}

The current Immigration Act restricts the right of the Minister of Citizenship and Immigration to participate directly in refugee hearings. Nevertheless, in any case where exclusion has been identified as an issue (i.e., on the basis that the claimant may have committed a war crime or a serious crime outside of Canada), a representative of the Minister is permitted to interveneand actively oppose the refugee application. The existing limitation on ministerial intervention is an important safeguard to ensure that refugee hearings remain non-adversarial. As noted by the Plaut Report in 1985,

[T] he adversarial system assumes that there are conflicting interests to be resolved by an impartial judge. In refugee determination, there is not (or should not be) an 'adversary' to the refugee. There do not exist, as in a civil suit, two parties with conflicting financial or other interests; nor are there, as in a criminal proceeding, the interests of the state confronting the accused. ${ }^{20}$

Rebuilding Trust, authored by James Hathaway in 1993, confirms that in acceding to the Refugee Convention Canada has agreed as anation to admit refugees. This implies that it is incumbent upon us to dispassionately

apply the relevant criteria rather than seeking either to promote or to challenge the applications presented to us ... [W] must not view refugee claimants as opponents or threats, but rather as persons seeking to invoke a right derived from international law. ${ }^{21}$

For the vast majority of cases, the participation of a Refugee Claims Officer in the hearing ensures that the tribunal has adequate assistance in questioning the claimant and providing a summary of relevant concerns at 
the conclusion of the hearing. Unrestricted ministerial intervention would likely invite increased levels of such intervention, a significant and inappropriate erosion of the principle of non-adversarial refugee adjudication.

\section{Improperly Documented Claims}

The government is proposing a series of measures, including the prospect of detention, aimed at addressing the issue of improperly documented refugees. These measures completely fail to account for the reality of the vast majority of "undocumented" refugee claimants arriving in Canada: people who come from countries with no central authority to issue documents or countries where the use of identity documents is limited and confined primarily to male, upper income residents of urban areas; people who have fled without having the time to acquire a passport or other identity documents; people who are unable to acquire such documents from the government as it is the very agent of persecution that the refugee is fleeing. In the face of expanded policing and interdiction practices around the world, many refugees fleeing persecution have no option but to use false documents and passports.

Commenting on the requirement in the current Immigration Act for refugees to provide satisfactory identity documents, the UNHCR noted that

recognized refugees $\ldots$ are effectively denied the right to family reunion and are not entitled to receive travel documents, as provided in Article 28 of the 1951 Convention. Another serious concern is that the inability to obtain permanent residence status can be a serious impediment to integration in Canadian society. ${ }^{22}$

While refugees without permanent residence are protected from refoulement, they face a myriad of barriers that result in severe hardship. In addition to family separation, access to post-secondary education, professional training programs and bank loans for small businesses and in many cases, even employment, is denied.
New Directions justifies the targeting of improperly documented refugee claimants under the rubric of maintaining the safety of Canadian society. Yet the government has provided no evidence of widespread danger. The refugee hearing itself provides an opportunity for extensive examination of identity issues. Refugee applications are turned down if it is found that the individual is not who he/she claims to be. Nevertheless, mistakes can be made. For the few who manage to obtain refugee status on the basis of misrepresentation or concealment of any material fact, proceedings can be initiated against the particular individual pursuant to existing provisions of the Immigration Act..$^{23}$ Given the extensive consultations between the Department and community representatives over the past six years with regard to this issue, the government's manifest capitulation to an agenda premised squarely on myths and misconceptions about refugees is particularly disturbing. ${ }^{24}$

\section{Undocumented Convention Refugee in Canada in Class}

New Directions proposes to reduce the waiting period from five to three years for refugees who are unable to obtain identity documents by reason of the absence of a central authority in their country of origin. New Directions is silent with regard to the plight of undocumented refugees who are unable to obtain documents for other reasons. The imposition of any waiting period and the concomitant restrictions which it entails discriminate against people who are without satisfactory identity documents through no fault of their own. The requirement for identity documents for Convention refugees and others seeking landing in Canada for risk-related reasons should be eliminated.

\section{Decision Makers}

New Directions proposes to improve recruitment and increase transparency in the selection process for decision makers, a proposal that is both sound and long overdue. Toensure that both Canadians and the refugee claimants whose very lives are atstake have confidence in the legitimacy and integrity of the tribunal, the appointment and re-appointment process must be depoliticized. The government should be encouraged to introduce legislative amendments to achieve these objectives immediately. Representatives of non-governmental organizations and the bar should be included in a reconstituted appointments advisory committee.

\section{Appeal on the Merits of \\ Protection Decisions}

Current reform proposals do not include the introduction of a right to appeal on the merits of a refused claim. As recognized by both the UNHCR and Amnesty International, the right to an appeal or review is an internationally accepted minimum standard for refugee determination. As noted in Not Just Numbers, the inclusion of an internal appeal mechanism is necessary for maintaining procedural fairness, correcting mistakes, and ensuring consistentinterpretations of thelaw, especially given the potentially life threatening consequences of an error in judgment. The existing system of judicial review with itsleave requirements and narrow grounds for review is extremely restrictive and for this reason fails to provide an effective remedy or substitute for an internal appeal.

\section{The Right of Landing Fee}

New Directions fails to address the injustice caused by the Right of Landing Free, a modern day "head tax" and the burdensome, non-refundable "processing fees." These up-front fees have a differentialimpact on refugees from the South where $\$ 975$ very often represents up to three years salary. The governmenthas claimed the fee is not discriminatory because it applies to everyone. Given the disparities between refugees in terms of incomeearned, however, the fee amounts to a regressive, flat tax that violates fiscal fairness. ${ }^{25}$ It has impeded family reunification, forced people who earn minimum wage to go hungry and incited a proliferation of loan sharks. ${ }^{26}$ The Refugee Convention obliges states to take active steps to facilitate the assimi- 
lation and naturalization of refugees and to reduce as far as possible the charges and costs imposed upon them. ${ }^{27}$ Instead of working to honour this commitment, New Directions proposes to levy an additional fee associated with a new permanent residence card.

The availability of a government loan program has done little to ameliorate the hardships caused by the right of landing fee. Many categories of refugees and others seeking landing for protection related reasons have been deemed "unlikely to repay" and denied the loans. Single women with children are disproportionately affected in this regard. Concerns about the right of landing fee have been raised by the Canadian Human Rights Commission ${ }^{28}$ and the National Action Committee for the Status of Women. The United Nations High Commissioner for Refugees conducted a survey and found no other country imposing such a fee on refugees. Even the Liberal party itself passed a resolution roundly calling for a "reexamination of fee." In light of the success of the government's deficit reduction strategy (the fee was originally defended as a necessary "trade-off" to preserve publicly funded settlement services while at the same time addressing the goals of debt and deficit reduction), the government should be encouraged to abolish the right of landing fee and avoid the imposition of any further cost recovery programs on refugees. The actual costs of other publicly funded programs are not borne so disproportionately by any narrowly defined usergroup. Those costs are shared by everyone and collected through the tax system based on the principle that those with the most resources contribute accordingly.

\section{Conclusion}

It should be evident from the foregoing review that the government's New Directions includes a number of positive proposals, which if developed effectively, stand to enhance meaningful protection for refugees and others at risk. At the same time, however, there are disturbing signals in the text of the propos- als as well as in the gaps and omissions which stand to chart a treacherous course for refugees seeking protection from Canada in the next millennium. Most ominously, the paper's proposals to enhance interdiction, "to intercept improperly documented people before they arrive in Canada, ${ }^{29}$ belies the government's professed commitment to refugee protection and suggests that there will be far fewer refugees arriving at our borders in the years to come. New Directionsmakes no reference to theneed for adequate safeguards to ensure that people fleeing persecution will be assured their right to seek asylum. In fact, as the case of the Tamils off the coast of Senegal last year aptly underscores, Canada already deploys a range of measures that prevents refugees from reaching safety. With the imposition of visa requirements and carrier sanctions to the stationing of immigration officers in airports abroad, vast numbers of bona fide refugees are increasingly caught up in a web of migration control measures with devastating results. ${ }^{30}$

Let us recall that many other western countries receive more refugees than Canada, both in terms of absolute numbers and per capita. As identified by the U.S.Committee for Refugees, year after year, Germany, the United Kingdom and the United States have each received more refugee claimants than Canada. ${ }^{31}$ The majority of the world's 15 million refugees come from and remain in countries of the South. Over the past few years the total refugee population in Canada, including persons resettled from overseas as well as persons who have made claims in Canada, has represented between nine and eleven percent of the country's overall immigration intake in any given year-for 1997 a mere 34,689 persons..$^{32}$ In the face of this reality the government's challenge will be to honour and extend the country's international legal commitments to refugees and others in desperate need of protection. Steps must be taken to stanch the anti-refugee sentiment that has gained ascendancy with the neo-liberal agenda over the past decade. Canada can and should assume a leading role in encouraging states toeradicate the human rights violations that are the root cause of all involuntary migration, while at the same time preserving access to asylum. For asylum, to paraphrase Atle GrahlMadsen, is the ultimate human right when every other safeguard has failed.

\section{Notes}

1. The government's comments were reported in an article in the Globe and Mail, 16 January 1999. The real story, however, had surfaced some five months earlier in two Amnesty International Bulletins: AIIndex, ASA 37/19/98; ASA 37/21/98.

2. United Nations Convention against Torture, Article 3.

3. Human Rights Watch, World Report 1999; U.S. Department of State, Country Reports on Human Rights Practices for 1997; Amnesty International, Amnesty International Report 1998: Sri Lanka.

4. In 1997Canada ignored a request from the Committee against Torture in the case of Tejinder Pal Singh and in 1998, from the Inter-American Commission on Human Rights in the case of Roberto San Vicente. See "Canada deports Venezuelan," The Globe and Mail, 13 March, 1998, A7; and Amnesty International, "Refugee Determination in Canada: The Responsibility to Safeguard Human Rights," Draft Response to the Government of Canada's White Paper, February 1999.

5. Amendments to the Immigration Act enacted in 1993 imposed the requirement on all Convention refugees to produce satisfactory identity documents in order to be landed. Thousands of Convention refugees are in legal limbo because they can't get documents. In 1997 regulations were adopted creating the "Undocumented Convention Refugee in Canada Class," imposing a five year waiting period for undocumented refugees from two designated countries, Somalia and Afghanistan, who were seeking landing. No measures were adopted for refugees from other countries.

6. “A Loyal Liberal is Branded a Terrorist Threat," The Globe and Mail, 10 February 1999, A1.

7. Singh et al. v. Canada (Minister of Employment and Immigration) [1985] 1 S.C.R. 177.

8. See Andrew Coyne, "The Case for open immigration," Next City, Winter 1995, 34.

9. Not Just Numbers: A Canadian Frameworkfor Future Immigration was made public on January 6, 1998. In the face of strong public opposition to some of the report's key rec- 
ommendations, particularly in the area of standardized language testing and the requirement that immigrant selection be predicated on a demonstrated knowledge of French or English, the Minister of Citizenship and Immigration quickly distanced herself from many of the report's more radical proposals.

10. Much of the commentary related to specific proposals is based on text the author proposals is based on text the author developed for inclusion in a policy brief for the Coalition for Just Immigration and Refugee Policy, an advocacy organization
based in Toronto.

11. Canadian Bar Association, New Directions, Draft Submissions on the Refugee Proposals, February 1999, 1.

12. At a Canadian Council for Refugees conference in Ottawa on November 26,1998, an official with the Department of Citizenship and Immigration acknowledged that there were approximately 300-350 cases of refugees in limbo on security grounds and that at least part of the problem rests with the over broad interpretation ofmembership in the definition of inadmissible classes pursuantto section 19 of the Immigration Act.

13. See, the Security Intelligence Review Commi ttee Annual Report 1997-1998 with regard to the role of the Canadian Security Intelligence Service in immigration securityscreening.

14. The white paper proposes to deny admission to members of a government against which Canada has approved sanctions pursuant to a resolution of the United Nations or other multilateral body; people smugglers; and people who make false declarations on their application for permanentresidence.

15. Convention relating to the Status of Refugees, Article 33(2).

16. Amnesty In ternational, supra note 4.

17. Conclusion 15 (XXX) 1979.

8. Canadian Bar Association, supra note 11, p.11.

19. Ibid., 19-20. The "safe country" designation is particularly problematic in the context of violence as well as lesbians and gay violence as well as lesbians and gay men we at serious risk in countries with otherwise satisfactory records of human rights compliance.

20. W. Gunther Plaut, Refugee Determination in Canada: Proposals for a Ne-UJ System: A Report to the Honourable Flora Report to the Honourable Flora MacDonald, Minister of Employment and Immigration (Ottawa:

Minister of Supply and services Canada, 1985), 122

Refuge, Vol. 18, No.1 (February 1999)
21. James C. Hathaway, Rebuilding Trust: Report of the Review of Fundamental Justice in Information Gathering and Dissemination at the Immigration and Refugee Board of Canada (Ottawa : Immigration and Refugee Board, 1993), 6-7.

22. Letter to Canadian Council for Refugees, 14 May 1997.

23. In these circumstances, section 69.2(2) of the Immigration Act permits the Minister, with leave of the Chairperson oftheIRB, to make an application to reconsider and "vacate" the refugee determination. New Directions proposes to eliminate the requirement for leave of the Chairperson so quire the Board would be required to conside all applications for revocation of refider

4. Dr. Mohamed Tabit, "Identity Documents and CIC Broken Promises," Refugee Update, Winter 1997.

25. Citizens for Public Justice, "What would it cost to remove the $\$ 975$ Right of Landing Fee," December 1998.

26. Canadian Council for Refugees, "Impact of the Right of Landing Fee," February, 1997.

27. Convention relating to the Status of Refugees, Article 34.

28. Canadian Human Rights Commission 1995 Annual Report.

29. New Directions, 47

30. In the first nine months of1997 there were 1,285 claims from the Czech Republic, primarily from Czech Roma, who were fleeing persecution at the hands of neonazi skinheads. The European Roma Rights Centre, the International Helsinki Federation and even Canada's own Research Directorate of the IRB docum the growing racist growing racist violence as well as local police complicity in attacks against the Rona community. Close to half of the Roma claims considered by the Board were accepted but in October 1997 the Canadian government imposed a visa requirement for all citizens of the Czech Republic, effectively preventing any other Roma refugees from seeking asylum in Canada. See, Canadian Council for Refugees, "Refugees in Canada: Canadian refugee and humanitarian immigration policy," 1998; Research Directorate, policy, 1958, Research Directorate, (Issue Paper, Roma in the Czech Rep

31. U.S. Committee for Refugees, World Refugee Survey 1998, for the period 1993-1997.

2. CIC Statistics compiled by the Canadian Council for Refugees, October 1998. o inalist in the 1997

Thomas \& Znaniecki Prize competition awarded by the International Migration Section of the American Sociological Association

Paths To EQuity

Cultural, Linguistic, and Racial Diversity in Canadian Early Childhood Education

by Judith $\mathrm{K}$. Bernhard, Marie Louise Lefebvre, Gyda Chud, and Rika Lange

Toronto: York Lanes Press, 1995 ;

ISBN 1-55014-277-1; 112 pages, size $8.5 \times 11 ; \$ 18.95$

Paths to Equity is based on an extensive nationwide study of 77 childcare centres in Montreal, Toronto, and Vancouver on the cultural, linguistic, and racial diversity in Canadian Early Childhood Education (ECE). The report presents the results this study on how the ECE system is responding to the increasing diversity of contemporary Canadian society.

A fully one third of teachers interviewed in this study responded, at the time of graduation from ECE programs, did not feel that they were well prepared to work effectively with children and parents from diverse backgrounds. In this groundbreakingstudy, the authors haveaddressed teachers' views on diversity in the education programs; parents difficulties in collaborating within the current education system; teachers' difficulties in understanding many "ethnic" parents; desire of many parents for better communication with staff, preferably in their own languages, and for more information about their individual children, and chances for effective input; and the evidence of some continuing problems with racism, irrespective of the good intentions of centre staff.

Paths to Equity will be of interest to ECE faculty, policymakers, centre supervisors and staff and others interested in the inclusion of diversity content in profes-

sional education programs. Available from:

Centre for Refugee Studies

Fax: (416) 736-5837

Email: refuge@yorku.ca 